\title{
Novel approach to quantify duodenogastric reflux in healthy volunteers and in patients with type I gastric ulcer
}

\author{
S A MÜLLER-LISSNER, C J FIMMEL, A SONNENBERG, N WILL, \\ W MÜLLER-DUYSING, F HEINZEL, R MÜLLER, AND A L BLUM \\ From the Triemli Hospital, Zürich, Switzerland
}

\begin{abstract}
SUMmARY A new method is described which allows simultaneous measurement of gastric emptying and duodenogastric reflux and avoids transpyloric intubation. After intragastric instillation of a liquid lipid meal in six healthy volunteers the fractional gastric emptying rate was $2.9 \pm 0.3$ in the upright and $2.5 \pm 0.6 \mathrm{SEM} \times 10^{-2} / \mathrm{min}$ in the supine position, respectively $(\mathrm{p}>0.5)$. The duodenogastric reflux rate (expressed as fraction of the intraduodenal amount of duodenal marker) was 0.30 (range $0.03-0.81)$ and $0.22(0.01-0.55) \times 10^{-2} / \mathrm{min}$, respectively $(\mathrm{p}>0.2)$. Atropine $(40 \mu \mathrm{g} / \mathrm{kg})$ decreased the supine gastric emptying rate to $1.1 \pm 0.2(\mathrm{p}<0.05)$ and increased the supine duodenogastric reflux rate to $2.74(0.04-9.80) \times 10^{-2} / \mathrm{min}(\mathrm{p}<0.05)$. Fasting duodenogastric reflux rate was similar in the supine and upright position, $0.49(0.04-0.89)$ and $0.42(0.06-0.97) \times 10^{-2} / \mathrm{min}$, respectively $(\mathrm{p}>0.5)$. Fractional gastric emptying rate was similar in 10 volunteers and 17 patients with type I gastric ulcer $\left(2 \cdot 1 \pm 0.4 \mathrm{vs} 1 \cdot 7 \pm 0 \cdot 2 \mathrm{SEM} \times 10^{-2} / \mathrm{min}\right.$, $\mathrm{p}>0 \cdot 2)$. Their duodenogastric reflux rates were also similar, $0.65(0.01-5 \cdot 24)$ vs 1.10 $(0 \cdot 01-10 \cdot 83) \times 10^{-2} / \mathrm{min}(\mathrm{p}>0 \cdot 5)$. We conclude therefore that (1) gastric emptying and both fasting and postprandial duodenogastric reflux are independent of the posture; (2) fasting and postprandial reflux are of similar magnitude; (3) atropine shows gastric emptying and increases duodenogastric reflux; and (4) patients with type I gastric ulcer have neither slowed gastric emptying nor increased duodenogastric reflux.
\end{abstract}

Duodenogastric reflux has been claimed to play a major role in the pathogenesis of gastric ulcer ${ }^{1-3}$ but exact measurement of reflux is still a problem. Methods used in previous studies were either qualitative ${ }^{4}$ or invasive,${ }^{5}$ or did not measure reflux but concentrations of bile in gastric juice, ${ }^{3}$ or had technical problems. ${ }^{6}$ In the present paper a method is described which allows quantitative measurement of duodenogastric reflux during emptying of a liquid test meal or in the fasting state and does not interfere with the gastroduodenal junction. This method was standardised in healthy volunteers. Duodenogastric reflux was measured both in the fasting and in the fed state, in dependence of the

Address for correspondence: Dr S A Müller-Lissner, Medizinische Klinik Innenstadt, Ziemssenstr 1, D-8000 München 2, F R Germany.

Received for publication 9 August 1982 posture and during infusion of atropine. Duodenogastric reflux in healthy volunteers was then compared with reflux in patients with type I gastric ulcer.

\section{Methods}

\section{GASTRIC INTUBATION}

The experiments lasted for 120 minutes. They were started at 8.30 am after an overnight fast. In postprandial experiments a single lumen oesophagogastric tube was used and in fasting experiments a double lumen tube was used. The tube was positioned with its tip in the lowest part of the stomach. Its position was checked by fluoroscopy. The fasting gastric contents were removed by intermittent suction for 15 minutes using an Egnell pump model EMP 171687. 


\section{GASTRIC MARKER}

Experiments in fasting subjects The instillation port of the gastric tube was near the cardia and the aspiration port was near the pylorus. The perfusion consisted of $50 \mu \mathrm{Ci}^{51} \mathrm{CrCl}_{2}$ in $200 \mathrm{ml}$ saline. It was given at a rate of $1.5 \mathrm{ml} / \mathrm{min}$. The gastric aspirates were pooled in 10 minute fractions.

Experiments in postprandial subjects At time zero, a $400 \mathrm{ml}$ test meal was instilled into the stomach. It consisted of $200 \mathrm{ml}$ Intralipid ${ }^{\circledR} 20 \%$ (Hausmann) and $200 \mathrm{ml}$ tap water and was labelled with $10 \mu \mathrm{Ci}$ ${ }^{51} \mathrm{CrCl}_{2}$. Intralipid ${ }^{\circledR} 20 \%$ is an aqueous emulsion of soy-bean oil $(200 \mathrm{~g} / \mathrm{l})$, egg lecithin $(12 \mathrm{~g} / \mathrm{l})$, and glycerol $(25 \mathrm{~g} / \mathrm{l})$. It has $2000 \mathrm{kcal} / \mathrm{l}$ and an osmolality of $280 \mathrm{mosm} / \mathrm{l}$. The intragastric volume was determined at 10 minute intervals using a marker dilution technique modified from George. ${ }^{7}$ A $400 \mathrm{ml}$ stock solution of $5 \%$ Intralipid ${ }^{\circledR}$ was labelled with 90 $\mu \mathrm{Ci}{ }^{51} \mathrm{CrCl}_{2}$. After withdrawal of a sample of the gastric contents, a bolus of the labelled solution was instilled. For two minutes, six to eight cycles of aspiration and reinjection were performed by quickly filling and emptying a $50 \mathrm{ml}$ syringe. Then another sample was withdrawn. In the first to the fourth mixing manoeuvre the aspiration and instillation volumes were $10 \mathrm{ml}$ and $20 \mathrm{ml}$, respectively. In the fifth to the eighth mixing manoeuvre the volumes were 15 and $30 \mathrm{ml}$, and in the ninth to twelfth manoeuvre 20 and $40 \mathrm{ml}$, respectively.

\section{DUODENAL MARKER}

HIDA $\left({ }^{99 \mathrm{~m}} \mathrm{Tc}-\mathrm{Sn}\right.$-2,6-diethylacetanilidoiminodiacetate, from Solco Nuclear, Switzerland) was used as duodenal marker. When infused intravenously it is cleared by the liver and enters the duodenum via the bile.

For the intravenous infusion, HIDA was dissolved in $500 \mathrm{ml}$ saline. The activity was $1 \mathrm{mCi}$ in postprandial and $0.5 \mathrm{mCi}$ in fasting studies. Total radioactivity of the solution was measured with a gamma camera equipped with a diverging low energy collimator (Searle) behind a water layer of 10 $\mathrm{cm}$ (depth of the duodenum, see below). The infusion was started 30 minutes before the beginning of the experiment at a rate of $200 \mathrm{ml} / \mathrm{h}$. During the experiment abdominal radioactivity was scanned with the gamma camera at five minute intervals for one minute (at minute three, eight, $13,18, \ldots, 113$, 118). The data were stored on disc by a computer (gamma 11, Digital Equipment Co, Maynard, Mass.). In addition, the radioactivity was continuously monitored on a screen. Two tablets containing $3 \mu \mathrm{Ci}$ of ${ }^{57} \mathrm{Co}$ were glued to the right and left side of the abdomen, respectively. The activity spots of these tablets were marked on the screen with a pencil. Thus, the position of the subject could easily be reproduced for each gamma camera recording.

\section{POSTURE}

In supine studies the subjects remained in the supine position throughout the experiment. In upright studies the subjects sat on a chair. They stood up one minute before the gamma camera recording and were positioned identically for each recording by means of the ${ }^{57} \mathrm{Co}$ activity spots as described above. Two minutes later, after the end of the gamma camera recording, they sat down again.

\section{SUBJECTS STUDIED}

\section{A HEALTHY VOLUNTEERS}

Fasting Six healthy volunteers (aged 22-42 years) were studied in the fasting state both in the upright and supine position in randomised order.

Postprandial Ten healthy volunteers (aged 25-39 years) were studied in the supine position. Six of these subjects were also examined in the upright position. The two studies were performed in randomised order. In the latter six subjects the supine studies were repeated during infusion of atropine. For this purpose $40 \mu \mathrm{g} / \mathrm{kg}$ atropine sulphate were added to the infusion.

\section{B PATIENTS}

After obtaining informed consent 17 patients with type I gastric ulcer ${ }^{8}$ were studied in the postprandial state in the supine position. Each ulcer was proved by endoscopy. Biopsies were taken from the ulcer itself (centre and wall) and from the surrounding macroscopically intact mucosa. Biopsies were read 'blindly' by a pathologist. In none of the cases was malignancy suspected on the basis of the macroscopical or microscopical aspect. No patients had experienced previous abdominal surgery or had gastric outlet obstruction. Details of the patients are given in the Table.

The time between two studies in the same subject was at least one week. The study protocol was approved by the local ethical committee.

\section{EVALUATION}

\section{Gastric and duodenal marker}

After completion of the study ${ }^{99 \mathrm{~m}} \mathrm{Tc}$ radioactivity was counted over the descending part of the duodenum by computer analysis of the stored data. The region of interest consisted of 150 cells on the screen. Triple samples of $1 \mathrm{ml}$ of all solutions (marker solutions, tests meals, gastric aspirates) were counted in a gamma scintillation spectrometer (model 5375, Packard) for one minute. The counts of ${ }^{51} \mathrm{Cr}$ were corrected for background and 
Table Characteristics and mean duodenogastric reflux rates of the patients studied

\begin{tabular}{|c|c|c|c|c|c|}
\hline \multicolumn{3}{|c|}{$\begin{array}{l}\text { Patient } \\
\text { sex, age (yr) }\end{array}$} & \multirow{3}{*}{$\begin{array}{l}\begin{array}{l}\text { Concomitant } \\
\text { diseases }\end{array} \\
\begin{array}{l}\text { Hypertension } \\
\text { Coronary heart } \\
\text { disease }\end{array}\end{array}$} & \multirow{3}{*}{$\begin{array}{l}\text { NOSAC* } \\
\text { No } \\
\text { No }\end{array}$} & \multirow{3}{*}{$\begin{array}{l}\begin{array}{l}\text { Reflux rate } \\
\left(\times 10^{-2} / \mathrm{min}\right)\end{array} \\
\begin{array}{r}10.83 \\
4.05\end{array}\end{array}$} \\
\hline $1 \mathrm{PV}$ & $\mathbf{M}$ & 57 & & & \\
\hline $2 \mathrm{MM}$ & $\mathbf{F}$ & 79 & & & \\
\hline $3 \mathrm{EH}$ & $\mathbf{M}$ & 63 & - & No & $1 \cdot 57$ \\
\hline $4 \mathrm{EH}$ & $\mathbf{F}$ & 75 & $\begin{array}{l}\text { Coronary heart } \\
\text { disease } \\
\text { Oesophagitis }\end{array}$ & No & 0.55 \\
\hline $5 \mathrm{ED}$ & $\mathbf{M}$ & 57 & - & No & 0.43 \\
\hline $6 \mathrm{CA}$ & $\mathbf{F}$ & 49 & Schizophrenia & No & $0 \cdot 32$ \\
\hline $7 \mathrm{BH}$ & $\mathbf{F}$ & 69 & Diabetes & No & $0 \cdot 27$ \\
\hline $8 \mathrm{KS}$ & $\mathbf{M}$ & 67 & Arthrosis & Yes & $0 \cdot 21$ \\
\hline 9 WW & $\mathbf{M}$ & 70 & Arthrosis & Yes & $0 \cdot 12$ \\
\hline $10 \mathrm{JM}$ & $\mathbf{M}$ & 62 & Arthrosis & Yes & 0.06 \\
\hline 11 PS & $\mathbf{F}$ & 57 & Oesophagitis & No & 0.05 \\
\hline $12 \mathrm{WZ}$ & $\mathbf{M}$ & 77 & - & No & 0.05 \\
\hline $13 \mathrm{HF}$ & $\mathbf{M}$ & 51 & $\begin{array}{l}\text { Arthrosis } \\
\text { Obesity }\end{array}$ & Yes & 0.03 \\
\hline $14 \mathrm{GH}$ & $\mathbf{M}$ & 54 & - & No & 0.02 \\
\hline $15 \mathrm{LB}$ & $\mathbf{F}$ & 71 & $\begin{array}{l}\text { Cerebral } \\
\text { atherosclerosis }\end{array}$ & No & 0.02 \\
\hline $16 \mathrm{EM}$ & $\mathbf{M}$ & 73 & - & No & 0.01 \\
\hline $17 \mathrm{BT}$ & $\mathbf{F}$ & 21 & - & No & 0.01 \\
\hline
\end{tabular}

* NOSAC $=$ treatment with non-steroidal anti-inflammatory compounds. Patients no. 3 and 7 are husband and wife. The husband (no. 3) developed symptoms two weeks after his wife.

irradiation of ${ }^{99 \mathrm{~m}} \mathrm{Tc}$ and vice versa. The counts of ${ }^{99 \mathrm{~m}} \mathrm{Tc}$ as measured both by the gamma camera and by the scintillation spectrometer were corrected for the decay of the nucleotide.

ACID

Acidity was determined by titrating $1 \mathrm{ml}$ samples of gastric aspirates with $0 \cdot 01$ molar $\mathrm{NaOH}$ to $\mathrm{pH} 7 \cdot 0$ using an automatic burette (Instrumenten-Gesellschaft, Zürich).

\section{MATHEMATICS}

Fasting experiments The recovery rate is $\left.\mathrm{w}=\mathrm{V}_{\mathrm{a}}\left[{ }^{51} \mathrm{Cr}\right]_{\mathrm{a}} / \mathrm{V}_{\mathrm{i}}{ }^{51} \mathrm{Cr}\right]_{\mathrm{i}}$, where $\mathrm{V}_{\mathrm{a}}$ is the volume aspirated from the stomach, $V_{i}$ is the volume instilled into the stomach, $\left[{ }^{51} \mathrm{Cr}\right]_{a}$ is the concentration of ${ }^{51} \mathrm{Cr}$ in the gastric aspirate, and $\left[{ }^{51} \mathrm{Cr}\right]_{i}$ is the concentration of ${ }^{51} \mathrm{Cr}$ in the gastric perfusion fluid. The amount of ${ }^{99 \mathrm{~m}} \mathrm{Tc}$ refluxed into the stomach per minute is ${ }^{99 m} \mathrm{Tc}_{\mathrm{G}}=\left[{ }^{99 \mathrm{~m}} \mathrm{Tc}\right]_{\mathrm{a}} \mathrm{V}_{\mathrm{a}} / \mathrm{w}$, where $\left[{ }^{99 \mathrm{~m}} \mathrm{Tc}\right]_{\mathrm{a}}$ is the concentration of ${ }^{99 \mathrm{~m}} \mathrm{Tc}$ in the gastric aspirate. The duodenogastric reflux rate expressed as fraction of intraduodenal ${ }^{99 m} \mathrm{Tc}$ is $\mathrm{r}={ }^{99} \mathrm{~m}^{\mathrm{T}} \mathrm{c}_{\mathrm{G}} /$ ${ }^{99 \mathrm{~m}} \mathrm{Tc}_{\mathrm{D}}\left(\mathrm{min}^{-1}\right)$, where ${ }^{99 \mathrm{~m}} \mathrm{Tc}_{\mathrm{D}}$ is the amount of ${ }^{99 \mathrm{~m}} \mathrm{Tc}$ in the duodenum. The gastric volume secretion rate is $s=V_{a} / w-V_{i}(\mathrm{ml} / \mathrm{min})$. The acid secretion rate is $h=A V_{a} / w(\mathrm{mmol} / \mathrm{min}$, where $A$ is the acidity of the gastric aspirate.
Postprandial experiments The total intragastric volume, $\mathrm{V}$ is calculated from the gastric marker concentration before and after mixing, and from the volume and marker content of the mixing fluid as described by George. ${ }^{7}$ The intragastric amount of gastric marker $\mathrm{G}_{\mathrm{G}}$ is (1) $\mathrm{G}_{\mathrm{G}}=\mathrm{V}\left[{ }^{51} \mathrm{Cr}\right]_{\mathrm{a}}$, where $\left.{ }^{51} \mathrm{Cr}\right]_{\mathrm{a}}$ is the concentration of ${ }^{51} \mathrm{Cr}$ in the gastric aspirate. The intragastric amount of duodenal marker $\left(D_{G}\right)$, expressed as fraction of the intraduodenal amount of duodenal marker $\left(D_{D}\right)$, is (2) $\mathrm{D}_{\mathrm{G}}=\mathrm{V}\left[{ }^{99 \mathrm{~m}} \mathrm{Tc}\right]_{\mathrm{a}} / \mathrm{D}_{\mathrm{D}}$, where $\left[{ }^{99 \mathrm{~m}} \mathrm{Tc}\right]_{\mathrm{a}}$ is the concentration of ${ }^{99 \mathrm{~m}} \mathrm{Tc}$ in the gastric aspirate. Two assumptions were made: (a) gastric emptying rate, duodenogastric reflux rate, and gastric secretion rate remain constant during the relatively short time interval of 10 minutes (otherwise they represent average values for this period); (b) gastric emptying is proportional to the actual intragastric volume. Thus, the change in the intragastric amount of gastric marker is described by (3) $\mathrm{dG}_{\mathrm{G}} / \mathrm{dt}=\mathrm{gG}_{\mathrm{G}}$, where $\mathrm{g}$ is the fractional gastric emptying rate $\left(\mathrm{min}^{-1}\right)$ and hence (4) $\mathrm{G}_{2}=\mathrm{G}_{1} \mathrm{e}^{-\mathrm{gt}}$, where the indices 1 and 2 refer to the beginning and the end of the time interval $t$, respectively. As the aqueous and the lipid phase of the gastric contents empty together ${ }^{10}$ a common emptying rate for both phases was calculated. The test meal empties from the stomach like the gastric marker. Thus, its amount $M$ remaining in the stomach is (5) $\mathbf{M}_{2}=\mathrm{M}_{1} \mathrm{e}^{-\mathrm{gt}}$. The difference $\mathrm{V}-\mathrm{M}$ is the volume of gastric secretion fluid plus the small amount of refluxed duodenal juice. All other volume and marker changes are described by the equation (6) $d A_{i} / d t=-g_{i}+a_{i}$, where $\mathrm{i}$ represents either duodenal marker (expressed as fraction of its intraduodenal amount), or acid, or secretion volume, $A_{i}$ is the intragastric amount of $i$, and $a_{i}$ is the rate by which $i$ is delivered to the stomach. Equation (6) is solved as follows: (7) $\mathrm{a}_{\mathrm{i}}=\left(\left(\mathrm{A}_{\mathrm{i} 2}-\mathrm{A}_{\mathrm{i} 1} \mathrm{e}^{-\mathrm{gt}}\right) / \mathrm{g}\right) /\left(1-\mathrm{e}^{-\mathrm{gt}}\right)$. The volume secretion rate includes fluid secreted by the stomach and refluxed duodenal juice.

The equations were applied to the data using a SESAM computer (Hannes Keller AG, Switzerland).

\section{VALIDATION STUDIES \\ GASTRIC MIXING}

Different volumes of the test meal were instilled into the stomach. The marker dilution technique was performed as outlined above. Then the stomach was emptied by manual aspiration. The calculated volume was compared with the measured volume.

BINDING OF HIDA AND ${ }^{51}$ CR TO THE GASTRIC MUCosA

In four experiments saline containing $2 \%$ poly- 
ethylene glycol 4000 (PEG), a currently used nonabsorbable marker, ${ }^{11}$ was labelled with HIDA and ${ }^{51} \mathrm{CrCll}_{2}$. A volume of $200 \mathrm{ml}$ of this solution was instilled into the stomach. Samples of $10 \mathrm{ml}$ were withdrawn at five minute intervals until the stomach was empty and analysed for PEG, ${ }^{12}{ }^{99 \mathrm{~m}} \mathrm{Tc}$, and ${ }^{51} \mathrm{Cr}$, respectively.

SECRETION OF ${ }^{99 m}$ TC BY GASTRIC MUCOSA

In six Heidenhain pouch dogs, $1 \mathrm{mCi}$ of HIDA dissolved in $15 \mathrm{ml}$ normal saline was infused intravenously at a rate of $6 \mathrm{ml} / \mathrm{h}$ over $2 \frac{1}{2}$ hours. Gastric juice was collected from the pouch for two hours beginning 30 minutes after the start of HIDA infusion. It was pooled in 10 minute fractions. From the 30 th to the 60 th minute of collection, $20 \mu \mathrm{g} / \mathrm{kg} / \mathrm{h}$, and from the 60th to the 120th minute, $80 \mu \mathrm{g} / \mathrm{kg} / \mathrm{h}$ of 4-methyl-histamine dihydrochloride were infused intravenously. In the samples, acidity and concentration of ${ }^{99 \mathrm{~m}} \mathrm{Tc}$ were determined and the outputs of acid and HIDA were calculated. For each 10 minute period, ${ }^{99 m} \mathrm{Tc}$ recovered from the pouch was expressed as fraction of ${ }^{99 \mathrm{~m}} \mathrm{Tc}$ infused so far and compared with the acid secreted by the pouch by linear regression analysis. The same calculations were performed for the studies in fasting human volunteers.

DISTANCE BETWEEN SKIN AND DUODENUM

The distance between skin and duodenum was determined by abdominal computed tomography in 50 subjects. Tomograms with abnormal abdominal findings were excluded from this series. Before tomography the subjects ingested a barium suspension which allowed identification of the descending duodenum. The distance between the skin and the anterior and posterior duodenal wall was measured.

\section{CALCULATION OF THE REFLUX RATE}

In three postprandial studies (one patient, and two volunteers treated with atropine) duodenogastric reflux was high and the stomach did not overlap the ascending duodenum. In another patient in which the stomach did not overlap the ascending duodenum $5 \mathrm{mCi}$ of HIDA instead of $1 \mathrm{mCi}$ were infused. Thus, in these four studies the intragastric ${ }^{99 m}$ Tc could be scanned. The change in the counts over the stomach were compared with the calculated duodenogastric reflux rate.

\section{STATISTICS}

In the validation studies linear regression analysis was used. Duodenogastric reflux rates, intragastrically accumulated duodenal marker, and intragastric concentration of ${ }^{99 \mathrm{~m}} \mathrm{Tc}$ were compared by using the Wilcoxon's rank sum test. The other data were normally distributed and were thus compared by Student's $t$ test. Paired tests were used when appropriate. Values are given as means \pm SEM and as means (range), respectively.

\section{Results}

VALIDATION STUdIES

The validation of gastric mixing is given in Fig. 1. HIDA and ${ }^{51} \mathrm{Cr}$ do not bind to the gastric mucosa as shown in Fig. 2. Figure 3 shows that ${ }^{99 \mathrm{~m}} \mathrm{Tc}$ appearing in the Heidenhain pouch is closely related to acid secretion, suggesting secretion of HIDA and/or free pertechnetate by the gastric mucosa. In man gastric recovery of ${ }^{99 \mathrm{~m}} \mathrm{Tc}$ was much higher than in dogs and not related to the acid secretory rate. Thus, nearly all gastric ${ }^{99 \mathrm{~m}} \mathrm{Tc}$ in man is refluxed from the duodenum and not secreted by the gastric mucosa.

The distance between skin and anterior duodenal wall was $10.3 \pm 0.3 \mathrm{~cm}$ and the diameter of the duodenum was $1.75 \pm 0.07 \mathrm{~cm}$. The data were normally distributed. The validation of the calculated duodenogastric reflux rate is shown in Fig. 4. It should be noted that the measured values but not the calculated values depend on the gastric emptying rate.

\section{FASTING EXPERIMENTS}

The recovery rate of the perfused marker was $0 \cdot 88 \pm 0 \cdot 03$. The posture did not affect the duodenogastric reflux rate. The rate amounted to 0.49

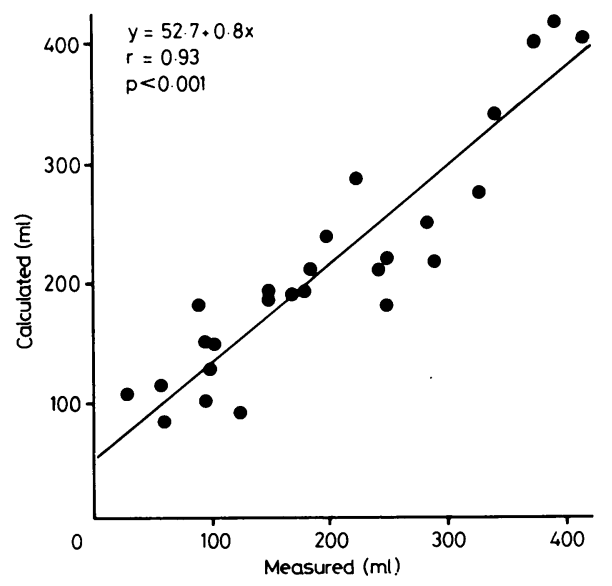

Fig. 1 Validation of gastric mixing. Measured volume expressed as (volume instilled before mixing + volume aspirated after mixing)/2 is compared with the volume calculated from the marker dilution. 


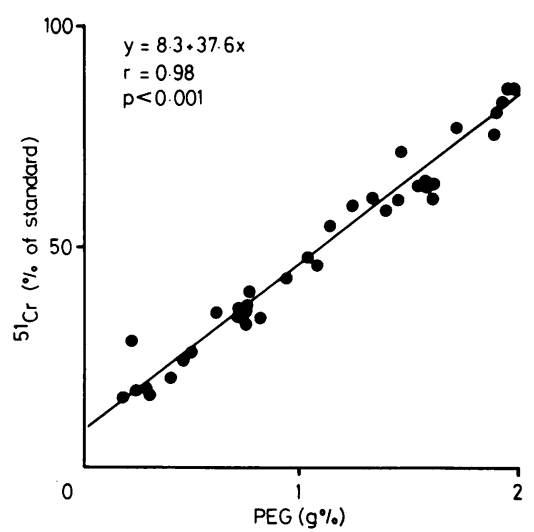

Fig. 2 Validation of the gastric and duodenal marker. A linear regression analysis between the concentrations of $P E G$ and ${ }^{5 l} \mathrm{Cr}$, respectively, is shown. ${ }^{51} \mathrm{Cr}$ values are expressed as per cent of ${ }^{5 l} \mathrm{Cr}$ concentration within saline test meal. Similar correlation exists between the concentrations of PEG and ${ }^{99 m} T c$.

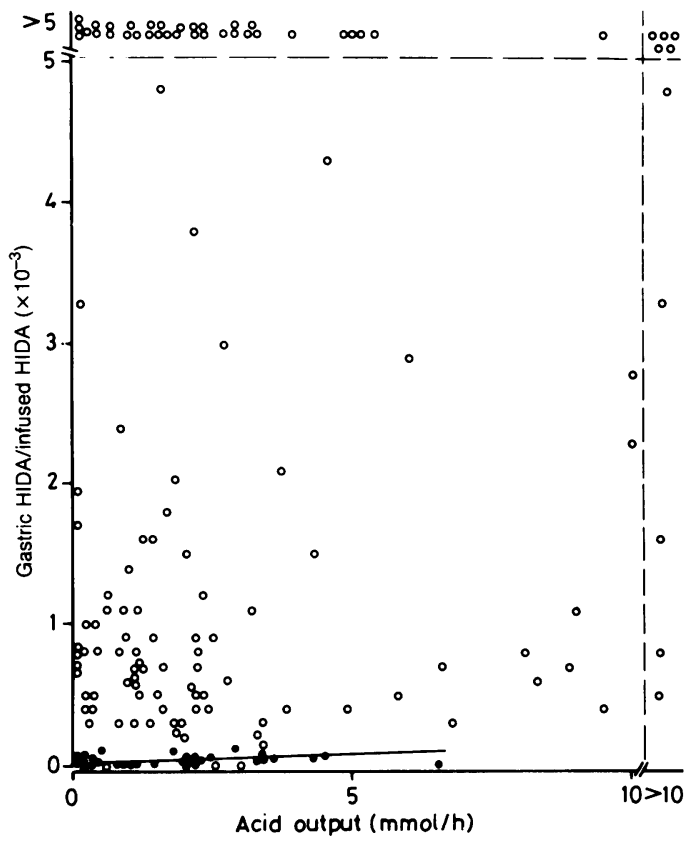

Fig. 3 Gastric secretion of acid and ${ }^{99 m}$ Tc. Close correlation is found in Heidenhain pouch dogs $(\bullet, y=1 \cdot 1$ $\times 10^{-5}+1.3 \times 10^{-5} \times x, r=0.62, p<0.01, t$ value of the slope $=5.81, p<0.001)$. Gastric recovery of ${ }^{99 m}$ Tc in man $(0)$ is much higher than in dogs and not related to acid secretion.
$(0.04-0.89)$ in the supine position and to 0.42 $(0.06-0.97) \times 10^{-2} / \mathrm{min}$ in the upright position $(\mathrm{p}>0 \cdot 5)$.

\section{POSTPRANDIAL EXPERIMENTS}

Posture The gastric emptying rates are shown in Fig. 5a. The mean rates did not significantly differ between upright and supine studies $(2.9 \pm 0.3 \mathrm{vs}$ $\left.2.5 \pm 0.6 \times 10^{-2} / \mathrm{min}, \mathrm{p}>0.5\right)$. The volume emptied $(7.0 \pm 0.6$ vs $5 \cdot 8 \pm 0.9 \mathrm{ml} / \mathrm{min}, \mathrm{p}>0.3)$ and the duodenogastric reflux rates, $0.30(0.03-0.81)$ vs 0.22 $(0.01-0.55) \times 10^{-2} / \mathrm{min}(\mathrm{p}>0.2$, Fig. $5 \mathrm{~b})$ were also similar. Thus, postprandial and fasting reflux were similar.

Atropine Atropine decreased fractional gastric emptying rate from $2 \cdot 5 \pm 0.6$ to $1 \cdot 1 \pm 0 \cdot 2 \times 10^{-2} / \mathrm{min}$ $(\mathrm{p}<0.05$, Fig. 5a). The volume emptied was decreased from $5 \cdot 8 \pm 0.9$ to $3 \cdot 1 \pm 0.3 \mathrm{ml} / \mathrm{min}$ $(\mathrm{p}<0 \cdot 05)$. Atropine increased duodenogastric reflux rate from $0.22(0.01-0.55)$ to $2.74(0.04-9.80)$ $\times 10^{-2} / \mathrm{min}(\mathrm{p}<0.05$, Fig. $5 \mathrm{~b})$. The volume secretion rate during infusion of atropine was $1 \cdot 9 \pm 0 \cdot 1 \mathrm{ml} / \mathrm{min}$. In the control studies, it was $3.9 \pm 0.9(\mathrm{p}<0.05)$. The acid secretion rate was reduced by atropine from $0.62 \pm 0.25$ to $0.27 \pm 0.15 \mathrm{mmol} \mathrm{H}^{+} / 10 \min (\mathrm{p}<0.05)$.

The time courses of the intragastric volumes and the intragastrically accumulated amount of the duodenal marker of the supine studies without and with atropine, respectively, are shown in Fig. 6. Gastric ulcer The mean gastric emptying rates and duodenogastric reflux rates of the 10 volunteers and the patients with gastric ulcers are shown in Fig. 7. In addition, the reflux rates of the patients are given in the Table. Statistically, they do not differ significantly. The mean emptying rates were $2 \cdot 1 \pm 0.4$ and $1.7 \pm 0.2 \times 10^{-2} / \mathrm{min}(\mathrm{p}>0.2)$ and the mean reflux rates were $0.65(0.01-5.24)$ and $1.10(0.01-10.38)$ $\times 10^{-2} /$ min $(p>0.5)$, respectively. Gastric volume and acid secretion tended to be lower in the patients but the difference was not statistically significant. The intragastric concentration of the duodenal marker was $180(8-1144) \mathrm{nCi} / \mathrm{ml}$ in controls and 460 $(4-2730)$ in patients $(p>0 \cdot 4)$. Duodenogastric reflux rates and gastric emptying rates did not significantly differ between patients treated or not treated with non-steroidal anti-inflammatory compounds.

\section{Discussion}

Of the many methods proposed to measure duodenogastric reflux, only those of Löhlein et al, ${ }^{13}$ Muhammed $e t a l,{ }^{14}$ and Tolin et at $t^{6}$ lend themselves to measure reflux rates in the absence of a transpyloric tube. They have the following disadvantages, however: (1) Gastric emptying and volume secretion cannot be measured because the concen- 

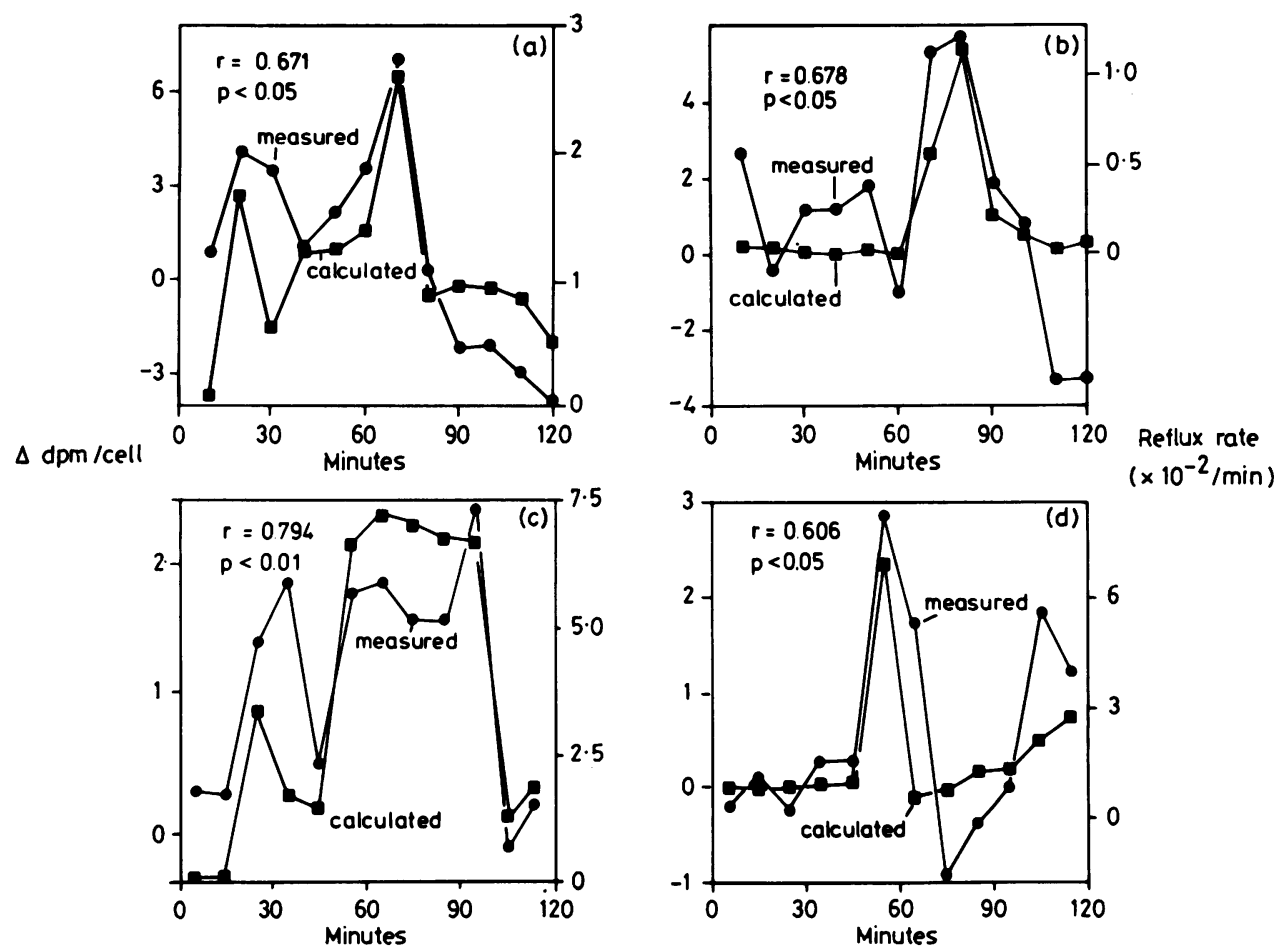

Fig. 4 Validation of calculation of duodenogastric reflux rate in four subjects where gastric scanning was feasible. Reflux rate $(\square)$ is compared with the change in intragastric ${ }^{99 m}$ Tc radioactivity as measured by scanning $(\bullet) ;(a)$ is from a patient with high duodenogastric reflux rate (no. 1), (b) is from an elderly patient with low reflux in whom $5 \mathrm{mCi}$ of HIDA had been infused (no. 8), (c) and (d) are from two atropine studies in volunteers.
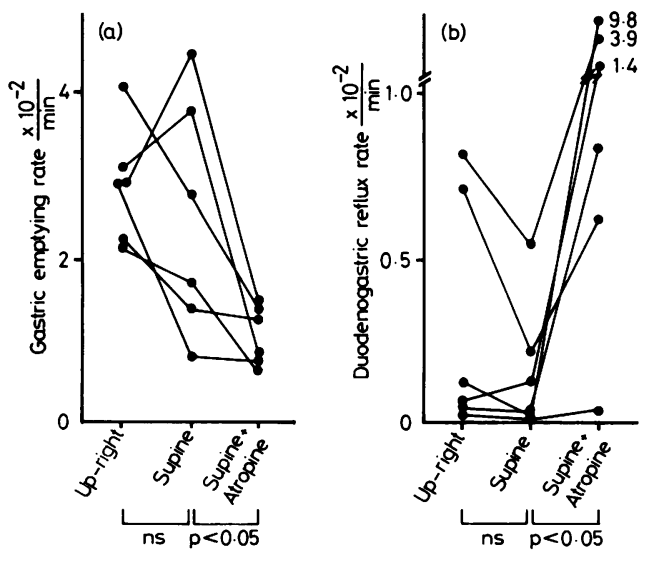

Fig. 5 Fractional gastric emptying rates (a) and postprandial duodenogastric reflux rates $(b)$ in volunteers studied in upright and supine position and in supine position during infusion of atropine. Each point represents mean of a 120 minute experiment. Values of same subject are connected with solid lines. $n s=$ statistically not significant. tration of the gastric marker is unknown. (2) The method of Tolin et al fails - at least in our hands - in more than half of the cases because there is a superposition between antrum and ascending part of the duodenum or between fundus and liver. (3) With low reflux rates the fraction and thus the amount of the duodenal marker inside the stomach is very small. Thus, accurate measurements require a high amount of duodenal marker. This poses ethical problems in young healthy volunteers.

The method described in the present paper avoids transpyloric intubation and has additional advantages: small intragastric amounts of the duodenal marker can be measured; furthermore, the determination of the concentration of the gastric marker allows the distinct calculation of gastric emptying and volume secretion.

A series of validation experiments was performed. ${ }^{51} \mathrm{Cr}$ and ${ }^{99 \mathrm{~m}} \mathrm{Tc}$ which were used as gastric and duodenal markers did not bind to the gastric mucosa (Fig. 2). The syringe induced mixing of the gastric marker within the gastric contents was complete and reliable (Fig. 1). The duodenal 

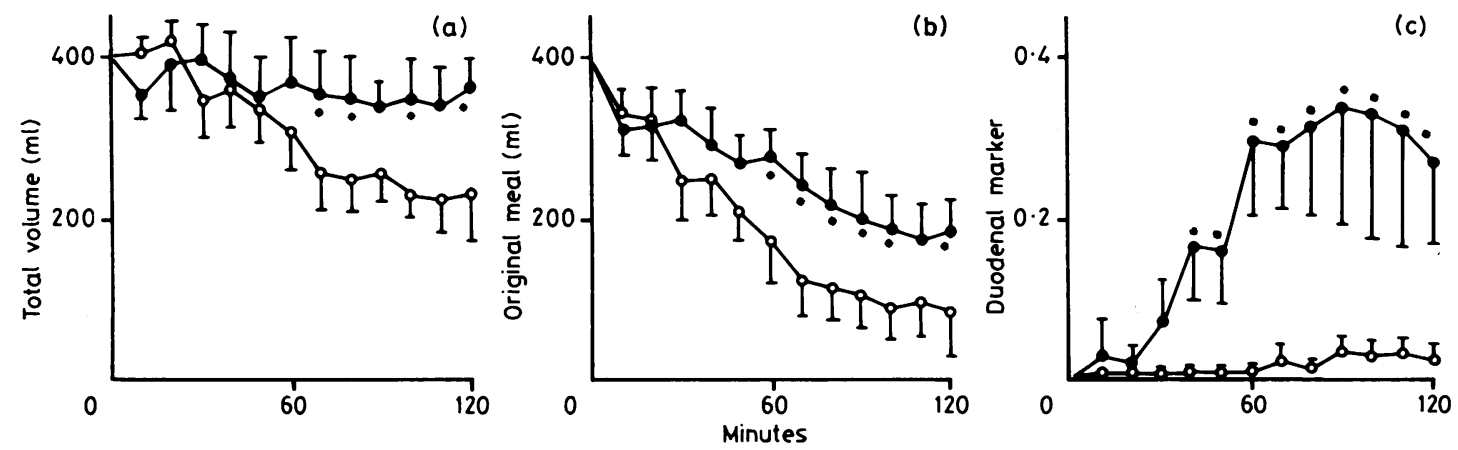

Fig. 6 Time course of intragastric volume (a), amount of original test meal remaining in stomach (b), and intragastrically accumulated duodenal marker (c) expressed as fraction of intraduodenal amount of duodenal marker in studies without $\left({ }^{-}-0\right)$ and with atropine $(\bullet-\bullet)$, respectively. Means $\pm S E M,{ }^{*} p<0.05$.

marker is secreted by the gastric mucosa to a negligible extent (Fig. 3). Gastric ${ }^{99 \mathrm{~m}} \mathrm{Tc}$, therefore, can be assumed to originate quantitatively from the duodenum. When the calculated duodenogastric reflux rates were compared with the change in the intragastric amount of duodenal marker a close correlation was found (Fig. 4). The use of the calculated reflux rate instead of the measured value has three distinct advantages: the calculated but not the measured value is corrected for gastric emptying; small rates can be measured; and super-
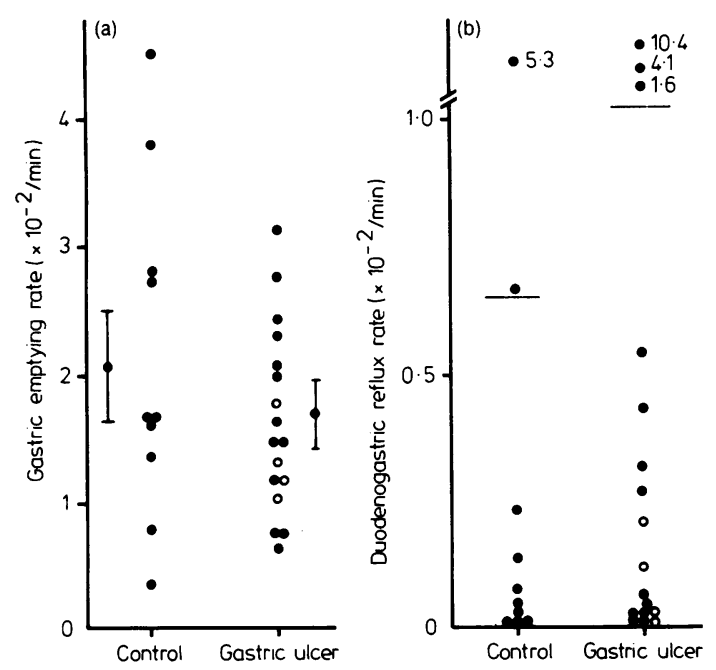

Fig. 7 Gastric emptying rates (a) and duodenogastric reflux rates $(b)$ in control subjects and gastric ulcer patients. Each point represents mean of 120 minute experiment. $\mathrm{O}=$ treatment with non-steroidal anti-inflammatory compounds. positions between stomach and small intestine do not affect the results.

Our method has, on the other hand, the following limitations: the reflux rate cannot be calculated in $\mathrm{ml} / \mathrm{min}$ because the duodenal concentration of the duodenal marker is unknown. The marker reflux as calculated is proportional to the volume reflux provided that the distance between skin and duodenum and the diameter of the duodenum show little interindividual variation. It could be shown that this is in fact the case. An improvement of our method would consist of measuring the duodenal radioactivity simultaneously from the abdomen and from the back, but such an apparatus was not available.

Duodenogastric reflux was found in all volunteers both in the fasting and the postprandial state. Interindividual variations were large (Figs 5b, 7b) while intraindividual variations were relatively small (Fig. 5b). They are, at least in part, because of the fact that duodenogastric reflux is discontinuous (Fig. 4). Other authors reported increased duodenogastric reflux in the upright position. ${ }^{15} 16 \mathrm{We}$ were unable to confirm these findings. Furthermore, in contrast with the dog, ${ }^{17} 18$ reflux was of similar magnitude in the fasting state and after a meal. Thus, reflux is neither affected by posture nor by the emptying of a liquid meal.

Gastric emptying was also independent of posture (Fig. 5a). Other authors did observe an acceleration in the upright position. ${ }^{19} 20 \mathrm{~A}$ possible explanation of this apparent difference may be related to the composition of the meal. A lipid meal may by activation of duodenal osmoreceptors slow gastric emptying and thus override the effect of posture. ${ }^{19}$

Atropine markedly increased the duodenogastric reflux rate (Fig. $5 b$ ). In addition, it decreased the 
gastric emptying rate (Fig. 5a) and the gastric secretion rate. Consequently, the total intragastric volume was higher during atropine administration than in control experiments (Fig. 6a). More of the original meal remained in the stomach (Fig. 6b) and, most importantly, the amount of the duodenal marker appearing in the stomach was much higher than in control experiments (Fig. 6c). During the second hour of the experiment more than a third of the duodenal marker was present in the stomach. We have previously reported similar findings on the effect of atropine on duodenogastric reflux, gastric emptying and gastric secretion in the dog. ${ }^{21}$ Atropine probably exerts its effect by inhibiting smooth muscle contractile activity. ${ }^{22} 23$ Interestingly, atropine has very little to no effect on the pyloric muscle. ${ }^{22}$ This, together with our failure to observe an increased duodenogastric reflux during emptying of a fatty meal casts some doubt on a major role of the pylorus in preventing duodenogastric reflux in man.

Patients with gastric ulcer had similar gastric emptying rates when compared with healthy controls (Fig. 7a). This is in agreement with previous reports where no delay in the emptying of liquid test meals was found in type I gastric ulcer. ${ }^{24-26}$ Delayed emptying of solids has been reported in this type of ulceration ${ }^{26-28}$ but this was not studied in the present paper.

Gastric ulcer patients did not differ from controls in their duodenogastric reflux rates (Fig. 7b). Some patients had very high reflux rates but this was also observed in the control group. The same holds true for the intragastric concentration of the duodenal marker. Most authors claim duodenogastric reflux to be increased in gastric ulcer patients. ${ }^{1-4} 5162629$ They have, however, either used the Capper test $^{4} 1516$ which allows no quantitative assessment of reflux or they measured intragastric bile acids. ${ }^{1-32629}$ Bile staining of gastric juice is not an accurate measurement of duodenogastric reflux. ${ }^{17}$ When reanalysing the data of Black et al ${ }^{1329}$ we found that the data are not normally distributed. Thus, only some patients had high 'reflux', a finding quite similar to our results. Also, Duane $e^{30}$ showed that even in patients with Billroth II resection - and thus high duodenogastric reflux - the intragastric concentration of bile acids and lysolecithin rarely reaches values necessary to produce mucosal damage. Thus, there is no evidence that gastric ulceration in general is because of increased duodenogastric reflux. Other factors such as nonsteroidal anti-inflammatory compounds ${ }^{31}$ and infectious agents $\mathrm{s}^{32}$ may be equally or even more important. This is consistent with the view that 'gastric ulcer are many different diseases'. ${ }^{34}$
In conclusion, duodenogastric reflux is a physiological event in healthy man. Gastric emptying and duodenogastric reflux are not affected by gastric emptying of a liquid meal and by the posture. In contrast, they can profoundly be changed by atropine. Gastric ulcer patients have on the average neither slowed gastric emptying nor increased duodenogastric reflux. In some patients, though, duodenogastric reflux might play a pathogenetic role.

This study was supported by Swiss National Foundation, grants no. 3.158/077 and 3.940/080, and by Deutsche Forschungsgemeinschaft grant no. Mu 629/1-1. We are indebted to Mrs M Lukachich for her excellent technical assistance.

\section{References}

1 Black RB, Roberts G, Rhodes J. The effect of healing on bile reflux in gastric ulcer. Gut 1971; 12: 552-8.

2 DuPlessis DJ. Pathogenesis of gastric ulceration. Lancet 1965; 1: 974-8.

3 Rhodes J, Barnardo DE, Phillips SF, Rovelstad RA, Hofmann AF. Increased reflux of bile into the stomach in patients with gastric ulcer. Gastroenterology 1969; 57: 241-52.

4 Capper WM, Airth GR, Kilby JO. A test for pyloric regurgitation. Lancet 1966; 2: 621-3.

5 Rees WDW, Go VLW, Malagelada JR. Simultaneous measurement of antroduodenal motility, gastric emptying, and duodenogastric reflux in man. Gut 1979; 20: 963-70.

6 Tolin RD, Malmud LS, Stelzer F, Menin R, Makler PT, Applegate G, Fisher RS. Enterogastric reflux in normal subjects and in patients with Billroth II gastroenterostomy. Gastroenterology 1979; 77: 102733.

7 George JD. New clinical method for measuring the rate of gastric emptying: the double sampling test meal. Gut 1968; 9: 237-42.

8 Johnson HD. Gastric ulcer: classification, blood group characteristics, secretion patterns and pathogenesis. Ann Surg 1965; 162: 99-1004.

9 Hunt JN, Spurrell WR. The pattern of emptying of the human stomach. J Physiol 1951; 113: 157-68.

10 Cortot A, Phillips SF, Malagelada JR. Gastric emptying of lipids after ingestion of an homogenized meal. Gastroenterology 1979; 76: 939-44.

11 Davis GR, Santa Ana CA, Morawski SG, Fordtran JS. Inhibition of water and electrolyte absorption by polyethylene glycol (PEG). Gastroenterology 1980; 79: 35-9.

12 Buxton TB, Crockett JK, Moore WL, Moore WL Jr, Rissing JP. Protein precipitation by acetone for the analysis of polyethylene glycol in intestinal perfusion fluid. Gastroenterology 1979; 76: 820-4. 
13 Löhlein D, Reichelt HG, Hundeshagen H, Pichlmayr R. Die Anwendung einer neuen Methode zur Bestimmung des duodeno- und jejunogastralen Reflux nach Magenoperationen. Chirurg 1977; 48: 588-91.

14 Muhammed I, McLoughlin GP, Holt S, Taylor TV. Non-invasive estimation of duodenogastric reflux using technetium-99m p-butyl-iminodiacetic acid. Lancet 1980; 2: 1162-5.

15 Cocking JB, Grech P. Pyloric reflux and the healing of gastric ulcer. Gut 1973; 14: 555-7.

16 Flint FJ, Grech P. Pyloric regurgitation and gastric ulcer. Gut 1970; 11: 735-7.

17 Müller-Lissner SA, Schattenmann G, Schenker G, Sonnenberg A, Hollinger A, Siewert JR, Blum AL. Duodenogastric reflux in the fasting dog: the role of pylorus and duodenal motility. Am J Physiol 1981; 241: G159-62.

18 Müller-Lissner SA, Sonnenberg A, Schattenmann G, Hollinger A, Siewert JR, Blum AL. Gastric emptying and postprandial duodenogastric reflux in pylorectomized dogs. Am J Physiol 1982; 242: G9-14.

19 Burn-Murdock R, Fisher MA, Hunt JN. Does lying on the right side increase the rate of gastric emptying? $J$ Physiol 1980; 302: 395-8.

20 McKelvey STD. Gastric incontinence and postvagotomy diarrhoea. Br J Surg 1970; 57: 741-7.

21 Sonnenberg A, Müller-Lissner SA, Schattenmann G, Siewert JR, Blum AL. Duodenogastric reflux in the dog. Am J Physiol 1982; 242: G603-7.

22 Golenhofen K, Lüdtke FE, Milenov K, Siewert R. Excitatory and inhibitory effects on canine pyloric musculature. In: Christensen J, ed. Gastrointestinal motility. New York: Raven Press, 1980: 203-10.

23 Lerman SH, Mason GR, Bathon EM, Ormsbee HS. Pyloric motor response to sympathetic nerve stimulation in dogs. Surgery 1981; 89: 460-5.
24 Buckler KG. Effects of gastric surgery upon gastric emptying in cases of peptic ulceration. Gut 1967; 8: $137-47$.

25 Griffith GH, Owen GM, Inst A, Campbell H, Shields R. Gastric emptying in health and gastroduodenal disease. Gastroenterology 1968; 54: 1-7.

26 Miller LJ, Malagelada JR, Longstretch GF, Go VLW. Dysfunctions of the stomach with gastric ulceration. Dig Dis Sci 1980; 25: 857-64.

27 Meves M, Beger HG. Die Magenentleerung bei Ulcus ventriculi. $Z$ Gastroenterol 1979; 4: 215-21.

28 Morguelan B, Ippoliti A, Sturdevant R. Gastric emptying in patients with gastric ulcer. (Abstract.) Gastroenterology 1979; 74: 1070.

29 Dewar EP, King RFGJ, Johnston D. Bile acid and lysolecithin concentrations in the stomach of patients with gastric ulcer - before operation, after HSV and after partial gastrectomy. (Abstract.) Gastroenterology 1981; 80: 1135 .

30 Duane WC, Wiegand DM, Gilberstadt ML. Intragastric duodenal lipids in the absence of a pyloric sphincter: quantitation, physical state, and injurious potential in the fasting and postprandial states. Gastroenterology 1980; 78: 1480-7.

31 MacDonald WC. Correlation of mucosal histology and aspirin intake in chronic gastric ulcer. Gastroenterology 1973; 65: 381-9.

32 Ramsey EJ, Carey KV, Peterson WL, Jackson JJ, Murphy FK, Read NW, Taylor KB, Trier JS, Fordtran JS. Epidemic gastritis with hypochlorhydria. Gastroenterology 1979; 76: 1449-57.

33 Sonnenberg A, Bartmess J, Kern L, Siebenmann RE, Joris F, Blum AL. Hypochlorhydrie bei akuter Gastritis. Dtsch Med Wochenschr 1979; 104: 1814-6.

34 Rotter JI. Gastric and duodenal ulcer are each many different diseases. Dig Dis Sci 1981; 26: 154-60. 